\title{
Epidemiological study of cholelithiasis among railroad workers in India with special reference to causation
}

\author{
S. L. MALHOTRA ${ }^{1}$ \\ From the Medical Department, Western Railway, Bombay, India
}

Important geographical and racial variations have been observed by several workers in the incidence of cholelithiasis in various parts of the world. Thus, the frequency rates reported among adult whites in Europe and the United States has varied between 7.5 and $22 \%$ but the disease is uncommon in the Negro (Curb, 1940; Jaffé, 1933; Ludlow, 1937). Maki (1961) and Kleeberg (1960) found the disease to be rare also among the Chinese and the Japanese.

Differences exist between countries even in the continent of Europe: Kozoll, Dwyer, and Meyer (1959) found much higher rates in Germany (32.6\%) and Sweden $(19.6 \%)$ while Torvik and Høivik (1960) reported an incidence rate of $19.5 \%$ in a necropsy series from Norway.

This paper attempts to study the incidence of the disease in a population of known constitution among the Indian railroad workers.

\section{MATERIALS AND METHODS}

The population and the methods of case finding are the same as described in our study of gastrointestinal cancers (Malhotra, 1967a). Briefly, the study concerns a popu${ }^{1}$ Present address: South Eastern Railway, Garden Reach, Calcutta 43, India. lation of 1.31 million railroad workers employed on the Indian railways and their families numbering 1.29 million, distributed in the various geographical regions, as shown in Table I. The period studied was from 1 January 1960 to 31 December 1964 . The hospital services for this population are provided almost exclusively by the group of 88 railway hospitals distributed throughout the country. The services provided are comprehensive and include all the specialties, and, since these railway hospitals provide a complete coverage for railwaymen and their families, the statistics from the different geographical areas are likely to be comparable and unaffected by bias.

TABLE I

POPULATION SEX-WISE IN THE DIFFERENT RAILWAY ZONES

\begin{tabular}{lrr} 
Railway Zone & Male & Female \\
\hline Western & 180,000 & 177,069 \\
Central & 225,000 & 221,336 \\
Southern & 187,000 & 183,955 \\
Northern & 192,000 & 188,873 \\
North-eastern & 100,000 & 98,372 \\
Northeast frontier & 85,000 & 80,580 \\
South-eastern & 150,000 & 147,557 \\
Eastern & 194,000 & 190,840 \\
& & \\
Total & & \\
& &
\end{tabular}

Total population $=2,601,582$

\begin{tabular}{|c|c|c|c|c|c|c|c|c|}
\hline \multirow[t]{2}{*}{ Railway Zones } & \multicolumn{2}{|c|}{ Surgical } & \multicolumn{2}{|c|}{ Radiological } & \multicolumn{2}{|c|}{ Clinical } & \multicolumn{2}{|c|}{ Not Proved ${ }^{1}$ (Rejected) } \\
\hline & $M$ & $F$ & $M$ & $F$ & $M$ & $\boldsymbol{F}$ & $\boldsymbol{M}$ & $F$ \\
\hline $\begin{array}{l}\text { Western } \\
\text { Southern } \\
\text { Northern } \\
\text { Central } \\
\text { Southeastern } \\
\text { Northeastern } \\
\text { Northeast frontier } \\
\text { Eastern }\end{array}$ & $\begin{array}{r}9 \\
27 \\
33 \\
7 \\
10 \\
3 \\
1 \\
6\end{array}$ & $\begin{array}{r}3 \\
10 \\
40 \\
6 \\
16 \\
14 \\
0 \\
19\end{array}$ & $\begin{array}{r}3 \\
0 \\
52 \\
3 \\
0 \\
6 \\
5 \\
6\end{array}$ & $\begin{array}{r}7 \\
0 \\
133 \\
3 \\
0 \\
10 \\
6 \\
9\end{array}$ & $\begin{array}{l}7 \\
0 \\
0 \\
1 \\
0 \\
0 \\
0 \\
3\end{array}$ & $\begin{array}{l}5 \\
0 \\
0 \\
0 \\
0 \\
0 \\
0 \\
5\end{array}$ & $\begin{array}{r}0 \\
0 \\
48 \\
0 \\
0 \\
6 \\
0 \\
0\end{array}$ & $\begin{array}{r}0 \\
0 \\
95 \\
1 \\
0 \\
21 \\
0 \\
0\end{array}$ \\
\hline Total & 96 & 108 & 75 & 168 & 11 & 10 & 54 & 117 \\
\hline
\end{tabular}

${ }^{1}$ Most of the rejocted cases appear to be of acute cholecystitis without stones. 
DIAGNOSTIC CRITERIA Only those cases which were proved radiologically or at operation have been included (definitive diagnosis). This also includes cases of typical gall bladder colic or dyspepsia showing a nonopacifying gall bladder but no definite gallstones (presumptive diagnosis).

ACCEPTED CASES A total of 639 cases were admitted to the provisional list. Of these 171 were rejected on a careful scrutiny of the case papers and the cholecystograms, because they did not satisfy the criteria of diagnosis or because the original diagnosis was acute cholecystitis, or because the information available was inadequate. The details of the rejected cases, which are all presumably cases of acute cholecystitis, are displayed in Table II. Of the 468 accepted cases, 204 were confirmed at operation, 243 by radiography showing gallstone opacities, and 21 were diagnosed by the typical colic with nonopacification of the gall bladder.

Table III shows the geographical distribution of these 468 proved cases in the various zones. Approximately half of this total number were from the Northern Zonal Railway, serving the north of the country. These cases have been used in determining the quinquennial incidence rates (cases first diagnosed $1960-64 \div$ population at risk).

The quinquennial incidence rates over the period 1960-64 in the various railway zones, expressed per 100,000 of the railway population, are set out in Table IV and show that big geographical differences exist in the prevalence of cholelithiasis in different parts of the country.

GEOGRAPHICAL DISTRIBUTION OF CASES Approximately one-half of the total cases in this series were from the

TABLE III

AGE AND SEX-WISE DISTRIBUTION OF CASES OF CHOLELITHIASIS (1960-64) IN THE DIFFERENT RAILWAY ZONES Population

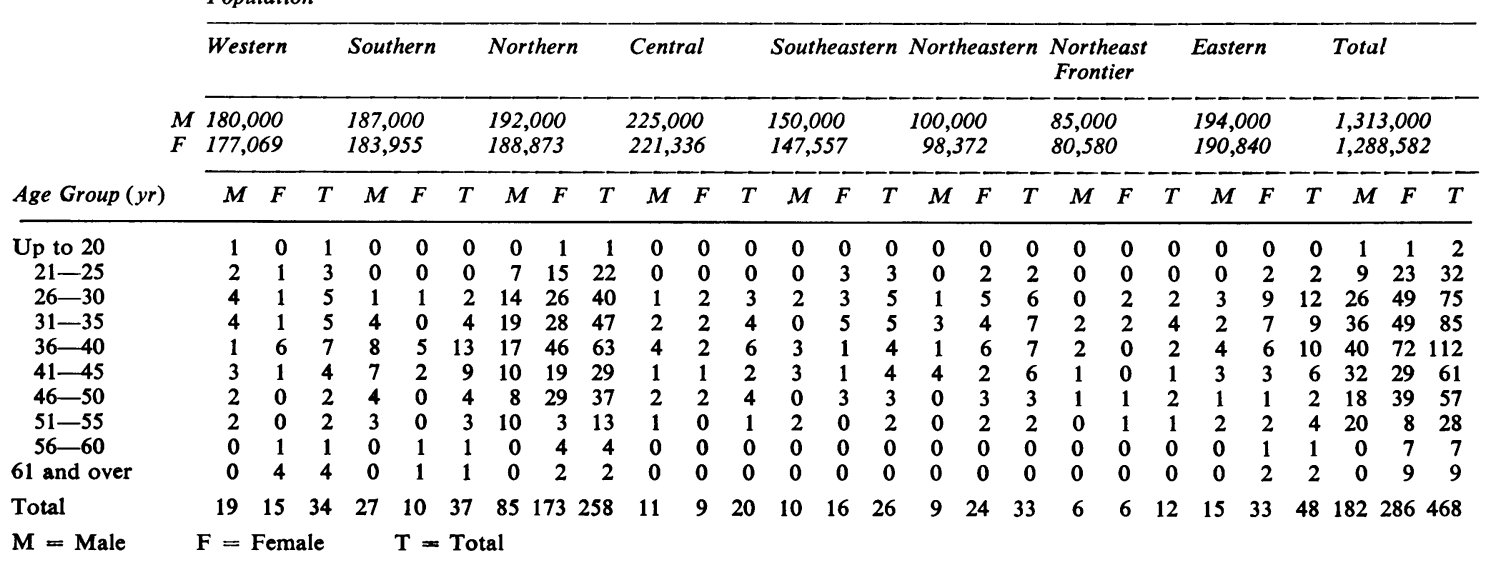

TABLE IV

QUINQUENNIAL (1960-1964) INCIDENCE-RATE OF CHOLELITHIASIS PER 100,000 OF RAILWAY POPULATION ON DIFFERENT RAILWAY ZONES

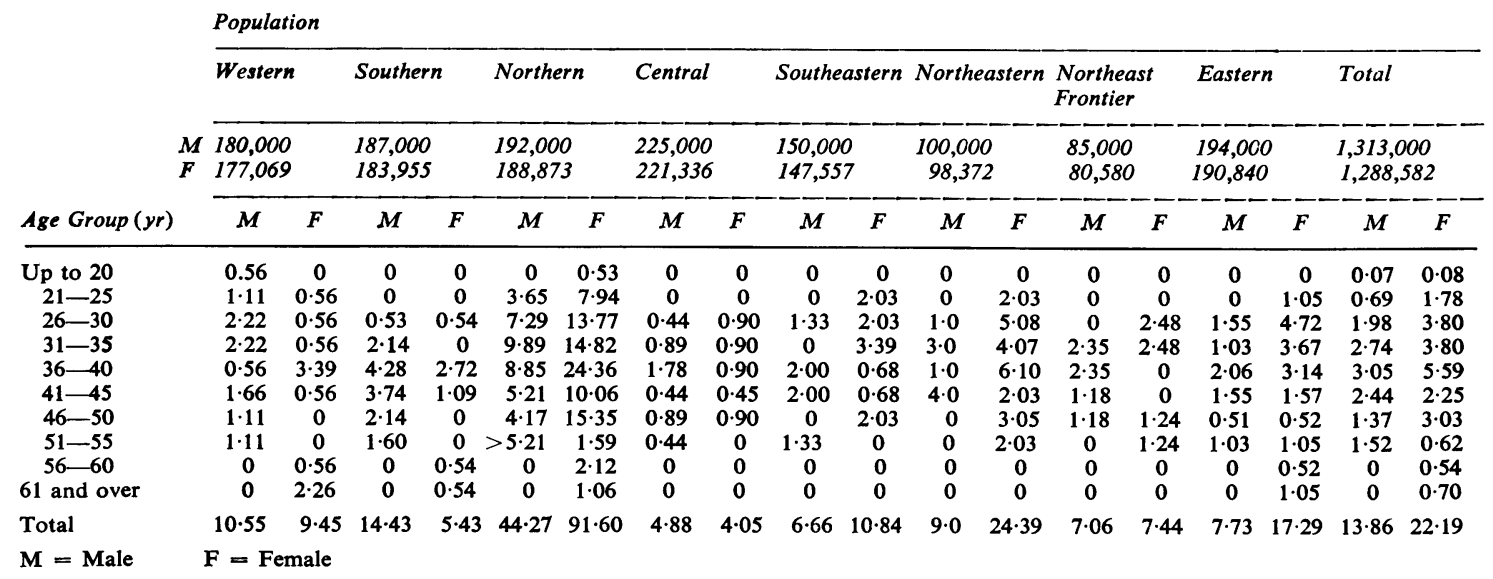


northern railway zone. The incidence rate is seven times more in the north as compared with the south $\left(\chi^{2}=27.8, \mathrm{P}<0.001\right)$. Even if only a proportion of the 143 rejected cases of acute cholecystitis of the Northern Railway might have concomitant cholelithiasis, the contrast in the incidence rates between the north and the south would become much bigger than shown by the data in Table IV.

SEX INCIDENCE The average incidence rate was higher in women as compared with men, the female/male sex ratio being $1.5: 1$ (Table IV). However, interesting geographical variations were present in sex incidence of the disease: thus while the females had a preponderance over the males in the north with a female/male ratio of $2: 1$, in the south the males showed a preponderance with an inverse female/male ratio of $1: 3$.

MEAN AGE The mean age of cholelithiasis in this survey was 39 years for the whole of the country, but here again we noticed differences between the north and the south, the mean age being 38 years for north Indians and 43 years for south Indians (Table V). Our youngest patient was a male, 9 years of age, and the oldest 75 years, a female.

AGE-SPECIFIC INCIDENCE Figure 1 shows that the agespecific incidence for cholelithiasis remained steady between 36 and 40 years for women after which it fell fairly steeply. This does not mean that the disease is less common in the older age groups, and this sharp decline in the incidence rates may be because the railwaymen retire at 55 years, and because the number of women at risk above 40 years will also be greatly reduced due to the superannuation from service of their husbands as discussed elsewhere, the female population in the age group

TABLE V

MEAN AGE OF PATIENTS ON ZONAL RAILWAYS

\begin{tabular}{llll} 
Railway Zones & \multicolumn{2}{c}{ Mean Age (in years) } & Combined \\
\cline { 2 - 3 } & Male & Female & \\
\hline Western & 35 & 45 & 40 \\
Southern & 42 & 43 & 43 \\
Northern & 38 & 38 & 38 \\
Central & 41 & 37 & 39 \\
Southeastern & 42 & 35 & 38 \\
Northeastern & 39 & 37 & 38 \\
Northeast frontier & 40 & 38 & 39 \\
Eastern & 40 & 38 & 39 \\
Mean & 39 & 39 & 39
\end{tabular}

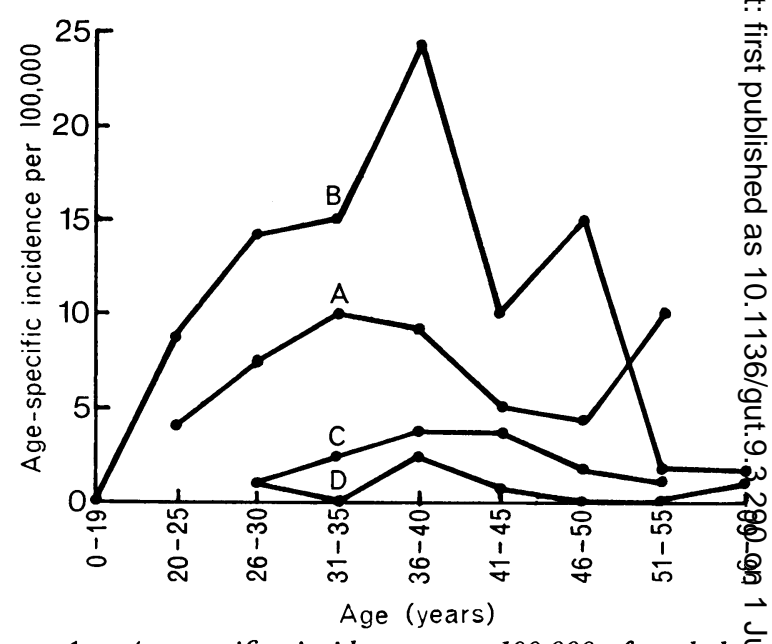

FIG. 1. Age-specific incidence per 100,000 for chole lithiasis on northern and southern railways. $A$, northern railway men; $B$, northern railway women; $C$, southern $\overrightarrow{0}$ railway men; $D$, southern railway women.

40 years and above representing widowed mothers only (Malhotra, 1967a).

SOCIOECONOMIC FACTORS In Table VI population and $\frac{2}{8}$ cases are divided among three socioeconomic strata as $\Rightarrow$ described earlier (Malhotra, 1967b). There is a remarkable윽 social gradient, the prevalence of cholelithiasis being the highest in the upper social classes of executives and the lowest in the low-income groups. The data suggest that the prevalence of the disease is 25 times more common ato을 the top than at the bottom of this socioeconomic scale? applied to this population. The reasons for this are totally윽 unclear.

\section{DISCUSSION}

In a retrospective survey of a disease in which all patients do not have symptoms it is impossible to․ㅡ․ determine the true incidence as many cases are $N$ likely to be overlooked. From the studies of Truesdell (1944) and Rothmann (1941) it may be possible to make the assumption that our figures $\omega$ represent at least a 10 -fold underestimate of the disease frequency, because for every 10 patients witho cholelithiasis nine are 'silent' and only one presents

TABLE VI

DISTRIBUTION OF 468 CASES OF CHOLELITHIASIS ANALYSED ACCORDING TO SOCIAL CLASS

\begin{tabular}{lcccc} 
Socioeconomic Index & Population at Risk & $\begin{array}{l}\text { No. of Cases of } \\
\text { Cholelithiasis }\end{array}$ & $\begin{array}{l}\text { Percentage of } \\
\text { Total Cases }\end{array}$ & $\begin{array}{l}\text { Prevalence Rate } \\
100,000\end{array}$ \\
\hline I \& II & 10,407 & 30 & 6.42 & 288 \\
III & $1,030,226$ & 228 & $48 \cdot 62$ & 22 \\
IV & $1,560,949$ & 210 & 44.96 & 13 \\
Total & $2,601,582$ & 468 & $100 \cdot 00$ & 2 \\
\end{tabular}


with symptoms (Bockus, 1965). Since, however, we are not so much concerned with the absolute incidence rates but are acutely interested in the relative geographical differences in the disease frequency, our data can provide valid geographical comparisons, as there is no reason why there might have been more 'silent' cases on one railway zone than on others.

A second source of error in our data which will almost certainly produce underestimates of frequency is the age structure of our population. The average patient with cholelithiasis is in the fifth decade at the time of operation or of establishment of the diagnosis (Bockus, 1965), and there is a steady increase in frequency with advancing years (Blumberg and Zisserman, 1942; Kozoll et al., 1959; Torvik and Høivik, 1960); our data must obviously represent underestimates of the absolute incidence rates in the general population because we are dealing with a younger population of railway employees between the ages of 18 and 55 years and a very small number of the widowed mothers over 50 years who are also entitled to be treated in the railway hospitals. Thus, our data do not help us to determine the incidence rates of the disease in the general population as a whole, but provide an index of the distribution of the disease in the age group 18-55 years among railway populations in India. Despite these limitations, since the age and sex structure of our population on the various railway zones is comparable because of the uniform procedures of recruitment, promotion, and superannuation in the various trades on the different zonal railways (Malhotra, 1967 ), our data can be expected to provide valid geographical comparisons between the incidence rates of the disease in the country.

The original data pertaining to various railway hospitals were based on the findings and diagnoses of many different physicians of inevitably varying competence, and, therefore, the criteria on which the diagnoses were made cannot have been identical throughout. This would apply especially to the 21 patients diagnosed clinically, as some physicians will have tended not to diagnose cholelithiasis in the absence of a definite $x$-ray shadow, and others would have hesitated to give a completely normal report in the presence of the distinctive clinical signs and symptoms alone. While such differences must have influenced the accuracy of the total incidence rates recorded in the study, they are unlikely to have affected the validity of the comparisons made between the different zones. On the contrary, the large number of physicians concerned introduces a random element, which in the absence of a single uniform opinion, is the best safeguard against bias in favour of any one group. The final selection of accepted cases was done by the author himself, based on the clinical data available from the case records of the various hospitals, and a bias in the geographical trends could have thus crept in. However, the distribution of the 171 rejected cases (Table II) shows that there were 143 rejected cases on the Northern Railway as against none on the Southern Railway, and the only evident resulting bias, therefore, lies in the direction of excluding possible cases in the Northern Railway group. As this will lower the incidence rate of the disease in the north as compared with the south, the bias in case selection will, on the other hand, tend to reduce the big differences between these two geographical areas.

AGE AND SEX Our data in Table IV are in keeping with the general observation that the frequency of gallstone disease is two to four times greater in women and that cholelithiasis occurs in women at an earlier age than in men (Jaffé, 1933; Robertson and Dochat, 1944). Jaffé (1933) found that while the relation between the white males and females was $1: 25$ it was $1: 10$ for the Negro. It is only in Japan that such sexual differences do not exist (Miyake and Ishyama, 1930). In our total data the male to female ratio of 1 to 1.5 is lower than the observations of Rolleston and McNee (1929) who found a male to female ratio of $1: 3$ in cases diagnosed clinically and of 5:12 in cases examined at necropsy. The reason for this discrepancy may be because our population has a much younger age group of women, who, being the wives of railway employees superannuating from service at the age of 55 years, would themselves be under 45 to 50 years of age. The male preponderance in South India is unexpected but is in keeping with Burnett's (1965) observation that in Australia there are more men affected by stones than in the corresponding group of men of the same racial stock in Britain. The reasons for this male preponderance in the south as compared with the female preponderance in the north are less clear and pose a problem in disentangling from the thicket of aetiology those factors which have a positive correlation with the disease.

GEOGRAPHICAL DISTRIBUTION OF CASES The total quinquennial rate of $18 / 100,000$ is low in comparison with the studies in the West (for a summary of western figures, see Jaffe, 1933). Rogers (1925) found an incidence of $5.4 \%$ among the general Indian population. Our total figures are lower than Roger's because of the lower age group of our population but our figures from the north are 
approximately four times higher than the total incidence rate and seven times higher than the incidence rate in the south. Our data showing variations in the geographical distribution in the incidence rates of the disease between different parts of the country are consistent with the variations noted by several workers between different countries (Jaffé, 1933; Kozoll et al., 1959; Torvik and Høivik, 1960). Such geographical variations in the incidence rates and the discrepancies in the sex incidence rates between the north and the south of the country suggest that environmental factors, probably dietary, may be implicated in the genesis of stone.

CHOLELITHIASIS AND PEPTIC ULCER This survey shows an inverse association between cholelithiasis and peptic ulcer because, while cholelithiasis is rare in the south, peptic ulcer is frequent, and while peptic ulcer is rare in the north, cholelithiasis is frequent. This striking inverse association between these two diseases makes one suspect that factors which promote the development of the one may prevent the development of the other; and it is tempting to suppose that a common factor may be implicated in both these diseases which, by virtue of its presence, causes the one, and by virtue of its absence, the other. This thesis finds support in the observations of Bernt (1960) and Bockus (1965) who encountered a greater frequency of cholelithiasis than expected following the Billroth II type of resection for peptic ulcer disease. It has been suggested that a lack of stimulation of the production of cholecystokinin as a result of the duodenal bypass in Billroth II could well be a factor by producing biliary stasis. In peptic ulcer patients with high acid curves, on the other hand, the gall bladder evacuation might be more rapid and stasis rare, because hydrochloric acid is the most potent duodenal stimulus for gall bladder evacuation (Hong, Magee, and Crewdson, 1956; Magee, 1965; Malhotra, 1966).

DIET AND GALL BLADDER STASIS A clinical impression exists that gallstones are more frequent in those who overeat fats and carbohydrates. This impression is borne out by the present data as the fat consumption of the north Indians (Punjabis) is eight to 19 times more than of the south Indians (Indian Council for Medical Research, 1964). Important differences in the fed fats exist between the north Indian versus the south Indian diets. Thus, while the north Indian dietary fats are saturated, these have a preponderance of short-chain $\left(\mathrm{C}_{4}-\mathrm{C}_{6}\right)$ fatty acid, triglycerides, whereas the south Indian seed oils are unsaturated but have a preponderance of long-chain fatty acid triglycerides
$\left(C_{18: 1}\right)$ such as oleic acid (Malhotra, 1967a, c, d). Sarles (1965) has shown that the degree of saturation of triglyceride fats did not affect gall bladder contraction: long-chain, liquid triglycerides produced better contraction than short; for example, oleic acid gave a marked contraction but butyric acid gave poor contractions. In other words, the short-chain dietary fats of the north Indians will lead to biliary stasis whereas the long-chain dietary fats of the south Indians will have the opposite effect.

Biliary stasis is considered by several investigators to be an important cause in the genesis of stone, bebecause if bile is held for a longer time than normal in the gall bladder there is an opportunity for increased absorption of water by the gall bladder wall and thus for concentrations of cholesterol above normal to be formed, leading to its precipitation and consequent stone formation. Burnett (1965) has shown that the liver can secrete a potentially lithogenic bile and after concentration by the gall bladder, the cholesterol in the bile approaches precipitation levels, with the bile acids and lecithinbile-salt system low and cholesterol levels now significantly raised.

Elsewhere we have demonstrated the effect of diet and the pattern of eating on gall bladder evacuation (Malhotra, 1966, 1968a, b). It was shown that evacuation was significantly lower in the north Indians on their masticatory diets as compared with the south Indians on their non-masticatory diets (Malhotra, 1966, 1968a) and this was due to the differences in their pattern of diet and eating (Malhotra, 1968b). These differences in the pattern of diet and eating of these two disparate groups (Malhotra, 1964) have been interpreted to mean that gall bladder evacuation is retarded by a masticatory diet as compared with the non-masticatory 'sloppy' diet (Malhotra, 1966, 1968a, b). The north Indian masticatory diet requires a lot of chewing and produces a salivary secretion of higher buffer capacity and higher mucus concentration (Malhotra, 1965; Malhotra, Saigal, and Mody, 1965, Malhotra, 1967e) which is better competent to neutralize gastric acidity (Malhotra, $1967 \mathrm{f}$ ). In contrast, the non-masticatory south Indian diets lack this competence. Since hydrochloric acid is the most potent duodenal stimulant of gall bladder evacuation (Magee, 1965), we suspect that masticatory meals produce gall bladder stasis by reducing the stimulus intensity of the hydrochloric acid for cholecystokinin release (Malhotra, 1967d, 1968a). Another possible explanation might be that since the amount of mucus in the gastric juice is significantly higher in the case of the masticatory meals when larger quantities of saliva mix with the meal (Malhotra et al., 1965; Malhotra, 1967e, f), in contrast to the 
sloppy and non-masticatory meals, the alteration brought about by acid in the physical state of this mucus will prevent the stimuli responsible for cholecystokinin release reaching the receptors: mucus is precipitated by strong acid and in this state might be less permeable to these stimuli. This probably also explains why gallstones are common in herbivora and ruminants and rare in carnivora (Bockus, 1965), as the bile remains stored in the gall bladder for a longer period in ruminants and at slaughter their gall bladders were found to be full whether the animals had been fed or fasted (Magee, 1965).

Thus the significantly higher incidence rates of cholelithiasis in the north Indians as compared with the south Indians suggest that dietary factors, especially the pattern of diet and eating, acting through gall bladder stasis, may be implicated in the pathogenesis of gallstones.

\section{SUMMARY}

The incidence of gallstones as 18 per 100,000 (quinquennial) has been established by a retrospective survey of Indian railroad employees between the ages of 18 and 55 years. Big geographical differences are present in the incidence rates, the disease being seven times more common in north Indians as compared with south Indians $(P<0.001)$. The mean age at diagnosis was 38 years among north Indians and 43 years among south Indians. While the disease was common in females in the north the position in the south was just the reverse. There is a peculiar inverse relationship of gall stones with peptic ulcer disease; where peptic ulceration is common, as in south India, gallstones are rare, and vice versa. The big geographical differences in the incidence rates of the disease and the varying male: female ratios suggest that environmental factors, mostly dietary, may be implicated. There is evidence to suggest that the pattern of diet and eating influences the gall bladder evacuation. The present data support the idea that gall bladder stasis is important in lithogenesis and this may be caused by the pattern of diet and eating.

\section{REFERENCES}

Bernt, O. (1960). Twelve cases of gall-stone after Billroth II noted in four years in East German Hospital. Dtsch. Gesundh.-Wes., 15, 402. Quoted by Bockus (1965).

Blumberg, N. and Zisserman, L. (1942). Cholelithiasis. Necropsy study. Rev. Gastroent., 9, 318-320.

Bockus, H. L. (1965). Cholelithiasis. In Gastroenterology, edited by H. L. Bockus, 2nd ed., vol. 3, pp. 746-782. Saunders, Philadelphia.
Burnett, W. (1965). The pathogenesis of gall-stones. In The Biliary System: A Symposium of the NATO Advanced Study Institute, edited by W. Taylor, pp. 601-618, Blackwell, Oxford.

Curb, D. L. (1940). Incidence of gallbladder disease in Negro. Bull. John Sealy Hosp., Univ. Texas, 2, 19. Quoted by Bockus (1965), vol. 3, p. 756.

Hong, S. S., Magee, D. F., and Crewdson, F. (1956). The physiological regulation of gallbladder evacuation. Gastroenterology, $30,625-630$.

Indian Council of Medical Research (1964). Diet Atlas of India. Govt. of India Press.

Jaffe, R. H. (1933). Cholelithiasis. A statistical study with special reference to its frequency in the coloured race. J. Lab. clin. Med., 18, $1220-1226$

Kleeberg, J. (1960). Etiology of gallstone formation in human beings. In Jubilee Volume, 100th Anniversary, Rudolph Virchow Medical Society, pp. 224-257. Karger, Basle and New York.

Kozoll, D. D., Dwyer, G., and Meyer, K. A. (1959). Pathologic correlation of gall-stones: a review of 1847 autopsies of patients with gall stones. Arch. Surg., 79, 514-536.

Ludlow, A. I. (1937). Autopsy incidence of cholelithiasis. Amer. J. med. Sci., 193, 481-482.

Magee, D. F. (1965). The physiology of the gall-bladder emptying. In The Biliary System: A Symposium of the NATO Advanced Study Institute, edited by W. Taylor, p. 235. Blackwell, Oxford,

Malhotra, S. L. (1964). Peptic ulcer in India and its aetiology, Gut, $5,412-416$

—, Saigal, O. N., and Mody, G. D. (1965). Role of saliva in the aetiology of peptic ulcer. Brit. med. J., 1, 1220-1222.

- (1966). Effect of diet and antacids on gall-bladder evacuation. Proc. 3rd Wld Congr. Gastroent. Tokyo, 2, 106.

- (1967a). Geographical distribution of gastrointestinal cancers in India with special reference to causation. Gut, 8, 361-372.

- (1967b). Epidemiology of ischaemic heart disease in India with special reference to causation. Brit. Heart J., 29, 895-905. $(1967 \mathrm{c})$. Serum lipids, dietary factors and ischemic heart disease. Amer. J. clin. Nutr., 20, 462-474.

- (1967d). Geographical aspects of acute myocardial infarction in India with special reference to patterns of diet and eating. Brit. Heart J. 29, 337-344.

- (1967e). A study of the effect of saliva on the concentration of mucin in gastric juice, and its possible relationship to the aetiology of peptic ulcer. Gut, 8, 548-555.

(1967f). Protective action of saliva in peptic ulceration. Scand.J. Gastroent., 2, 95-104.

- (1968a). Effect of diet on faecal and urine urobilinogen excretion and its possible relationship to the pathogenesis of peptic ulceration. Gut, 9, 183-186.

(1968b). Effect of patterns of eating and antacids on faecal urobilinogen excretion. Ibid., 9, 38-41.

Maki, T. (1961). Cholelithiasis in the Japanese. Arch. Surg., 82, 599-612.

Miyake, H., and Ishyama, F. (1930). Statistische und Klinische Studien auf Grund von 754 Fällen von Cholelithiasis-operationen bei Japanern. Dtsch. Z. Chir., 225, 187-214. Quoted by Jaffé (1933).

Rains, A. J. H. (1962). Researches concerning the formation of gallstones. Brit. med. J., 2, 685-691.

Robertson, H. E., and Dochat, G. R. (1944). Pregnancy and gallstones: collective review. Int. Obstet. Surg., 78, 193-204.

Rogers, L. (1925). Pathological evidence bearing on disease incidence in Calcutta. Glasgow med. J., 103, 1. Quoted by Jaffe (1933).

Rolleston, H., and McNee, J. W. (1929). Diseases of the Liver, Gall-bladder and Bile-ducts, 3rd ed. Macmillan, London.

Rothmann, H. (1941). Predilection of women for gallstone formation. Rev. Gastroent., 8, 148-154.

Sarles (1965). Quoted from The Biliary System. A symposium of the NATO Advanced Study Institute, edited by W. Taylor, Blackwell, Oxford.

Torvik, A., and Høivik, (1960). Gallstones in an autopsy series. Acta chir. scand., 120, 168-174. Quoted by Bockus (1965), vol. 3, p. 761 .

Truesdell, E. D. (1944). The frequency and future of gallstones believed to be quiescent or symptomless. Ann. Surg., 119, 232-245. 